\title{
LINGKUNGAN KELUARGA SEBAGAI SUMBER STIMULASI UTAMA UNTUK PERKEMBANGAN KOGNITIF ANAK USIA PRASEKOLAH
}

\author{
Elmanora $^{1^{*}}$, Dwi Hastuti ${ }^{2}$, Istiqlaliyah Muflikhati $^{2}$ \\ ${ }^{1}$ Program Studi Pendidikan Guru PAUD, Jurusan IImu Pendidikan, Fakultas Keguruan dan IImu Pendidikan, \\ Unversitas Jambi, Muaro Jambi 36361, Indonesia \\ ${ }^{2}$ Program Studi IImu Keluarga dan Perkembangan Anak, Sekolah Pascasarjana Institut Pertanian Bogor,
} Bogor 16680, Indonesia

${ }^{*}$ E-mail: elma.nora@yahoo.com

\begin{abstract}
Abstrak
Penelitian ini bertujuan untuk menganalisis pengaruh karakteristik anak, karakteristik keluarga, kualitas lingkungan pengasuhan, dan kualitas pendidikan prasekolah terhadap perkembangan kognitif anak di Kota Sungai Penuh, Provinsi Jambi. Contoh adalah 120 anak yang mengikuti pendidikan prasekolah formal (kelompok formal) dan nonformal (kelompok nonformal) dan ibunya yang dipilih dengan cara stratified random sampling. Contoh berasal dari delapan pendidikan prasekolah (empat pendidikan prasekolah formal dan empat pendidikan prasekolah nonformal). Data dikumpulkan dengan cara wawancara dan observasi. Analisis data menggunakan analisis deskriptif, uji beda t, dan analisis jalur. Keluarga dengan anak yang mengikuti pendidikan prasekolah formal memiliki pendidikan ibu, pendapatan keluarga per kapita per bulan, dan kualitas lingkungan pengasuhan yang lebih tinggi dibandingkan keluarga dengan anak yang mengikuti pendidikan prasekolah nonformal. Kualitas pendidikan prasekolah formal juga lebih baik dibandingkan kualitas pendidikan prasekolah nonformal. Perkembangan kognitif anak dipengaruhi oleh usia anak, pendidikan ibu, pendapatan keluarga, kualitas lingkungan pengasuhan, jenis pendidikan prasekolah, dan kualitas pendidikan prasekolah. Berdasarkan hasil analisis jalur, stimulasi dari lingkungan keluarga memiliki pengaruh yang lebih kuat pada perkembangan kognitif anak dibandingkan dengan stimulasi dari lingkungan sekolah.
\end{abstract}

Kata Kunci: anak usia prasekolah, HOME, lingkungan keluarga, pendidikan ibu, pendidikan anak usia dini

\section{Family Environment as a Sources of Main Stimulation for Preschool Children's Cognitive Development}

\begin{abstract}
This study aimed to analyze the influence of child characteristic, family characteristics, quality of home environment, and quality of preschool education on child's cognitive development in Sungai Penuh City, Jambi Province. The samples were 120 children who are attending formal (formal group) and nonformal (nonformal group) preschool education and her/his mother that were selected by stratified random sampling. The samples choosed from eight preschool education (four formal and four nonformal). Data collected by interview and observation. Data analysis used descriptive analysis, independent samples t-test, and path analysis. Formal group families had higher mother's education, family income, and the quality of home environment than nonformal group families. Quality of formal preschool education also better than quality of nonformal preschool education. The preschool children's cognitive development was influenced by the child's age, maternal education, family income, quality of home environment, the type of preschool education, and quality of preschool education. Stimulation from family environment had stronger effect on child's cognitive development than stimulation from school environment.
\end{abstract}

Keywords: early childhood education, family environment, HOME, mother's education, preschool children

\section{PENDAHULUAN}

Kualitas seorang individu dewasa tidak terlepas dari pengalaman dan perkembangan pada periode sebelumnya, salah satunya adalah periode usia prasekolah. Salah satu ranah perkembangan yang penting pada periode prasekolah adalah perkembangan kognitif. Menurut Grantham-McGregor (2007), per- kembangan kognitif yang optimal pada usia prasekolah menjadi salah satu penentu utama keberhasilan sekolah anak di tahapan selanjutnya.

Pencapaian perkembangan anak yang optimal membutuhkan peran lingkungan yang ada di sekitar anak. Menurut Heckman (2008), lingkungan pertama yang dapat membantu 
dalam mengoptimalkan perkembangan anak adalah lingkungan keluarga. Lingkungan keluarga berperan melalui penyediaan lingkungan pengasuhan yang berkualitas untuk anak. Penelitian yang telah dilakukan di beberapa kota/kabupaten di Indonesia menemukan bahwa lingkungan pengasuhan yang disediakan oleh keluarga untuk anak usia prasekolah masih belum optimal (Hastuti \& Alfiasari, 2008; Rahmaulina \& Hastuti, 2008; Latifah, Alfiasari, \& Hernawati, 2009; Latifah, Hastuti, \& Latifah, 2010; Hastuti, Fiernanti, \& Guhardja, 2011)

Setelah keluarga, lingkungan lain yang juga berperan pada perkembangan anak usia prasekolah adalah lingkungan sekolah yaitu pendidikan prasekolah. Pendidikan prasekolah diharapkan dapat membantu keluarga dalam memberikan stimulasi untuk mencapai perkembangan anak yang optimal terutama pada anak dengan kualitas lingkungan pengasuhan rendah.

Tidak semua pendidikan prasekolah dapat memberikan keuntungan bagi perkembangan anak karena manfaat pendidikan prasekolah bergantung pada kualitas dari pendidikan prasekolah tersebut (Barnett, 1995). Pendidikan prasekolah yang berkualitas dapat menghasilkan anak dengan perkembangan kognitif dan sosial yang lebih baik (Barnett \& Ackerman, 2006), mengurangi masalah keterlambatan perkembangan kognitif pada anak (Ramey et al., 2000), dan meningkatkan kesiapan belajar anak (Anderson et al., 2003). Sementara itu, pendidikan prasekolah yang tidak berkualitas dapat mematikan kreativitas anak (Santrock, 2009).

Keluarga dan sekolah sebagai lingkungan yang berinteraksi langsung dengan anak usia prasekolah berperan penting dalam menentukan perkembangan kognitif anak usia prasekolah. Oleh karenanya, kajian mengenai pengaruh stimulasi dari lingkungan keluarga melalui kualitas lingkungan pengasuhan dan pengaruh stimulasi dari lingkungan sekolah melalui kualitas pendidikan prasekolah terhadap perkembangan kognitif anak pada usia prasekolah sangat diperlukan untuk mencapai perkembangan kognitif anak yang optimal.

Secara umum, penelitian ini bertujuan untuk menganalisis pengaruh stimulasi dari lingkungan keluarga dan lingkungan sekolah terhadap perkembangan kognitif anak yang mengikuti pendidikan prasekolah formal dan nonformal. Secara khusus, penelitian ini bertujuan untuk menganalisis perbedaan kualitas lingkungan pengasuhan, kualitas pendidikan prasekolah, dan perkembangan kognitif antara anak yang mengikuti pendidikan prasekolah formal dan nonformal. Penelitian ini juga bertujuan untuk menganalisis pengaruh karakteristik anak, karakteristik keluarga, kualitas lingkungan pengasuhan, dan kualitas pendidikan prasekolah terhadap perkembangan kognitif anak yang mengikuti pendidikan prasekolah formal dan nonformal. Penelitian ini diharapkan juga mampu menemukan lingkungan yang paling berpengaruh terhadap perkembangan kognitif anak usia prasekolah.

\section{METODE}

Artikel ini menyajikan sebagian dari hasil penelitian tesis yang berjudul "Pengaruh Kesejahteraan Keluarga, Kualitas Lingkungan Pengasuhan, dan Kualitas Pendidikan Prasekolah terhadap Perkembangan Kognitif Anak". Penelitian yang dilakukan merupakan penelitian eksplanatori dan dilaksanakan dalam satu waktu (cross sectional). Penelitian dilakukan di Kota Sungai Penuh, Provinsi Jambi. Lokasi penelitian dipilih secara purposive dengan pertimbangan bahwa Kota Sungai Penuh merupakan kota dengan Angka Partisipasi Kasar Pendidikan Anak Usia Dini (APK PAUD) terendah di Provinsi Jambi. Data penelitian dikumpulkan pada bulan April sampai dengan bulan Juni tahun 2014.

Populasi dalam penelitian ini adalah anak usia prasekolah yang mengikuti pendidikan prasekolah formal (Taman Kanak-Kanak/TK) dan nonformal (Kelompok Bermain/KB) di Kota Sungai Penuh, Provinsi Jambi. TK dan KB dipilih karena merupakan pendidikan prasekolah dengan jumlah lembaga dan jumlah siswa terbanyak di Kota Sungai Penuh. Pada tahun 2013, Kota Sungai Penuh memiliki 35 lembaga pendidikan prasekolah formal dengan jumlah peserta didik sebanyak 1.700 anak dan 59 lembaga pendidikan prasekolah nonformal dengan jumlah peserta didik sebanyak 1.887 anak. Penarikan contoh penelitian dilakukan dengan cara stratified random sampling. Penarikan contoh diawali dengan pemilihan pendidikan prasekolah yaitu empat pendidikan prasekolah formal dan empat pendidikan prasekolah nonformal secara acak. Kegiatan selanjutnya adalah perizinan dan pendataan siswa yang memenuhi kriteria sebagai contoh penelitian, yaitu: (1) anak berusia 42-65 bulan, (2) anak aktif mengikuti pendidikan prasekolah formal dan nonformal, (3) anak berasal dari keluarga utuh, dan (4) anak bertempat tinggal di Kota Sungai Penuh. Setelah data terkumpul, 
15 orang anak dari kerangka contoh dipilih secara acak untuk menjadi contoh penelitian. Dengan demikian, total contoh yang terlibat dalam penelitian ini adalah 120 anak dan ibunya dari delapan lembaga pendidikan prasekolah.

Data yang dikumpulkan dalam penelitian ini adalah data primer yang terdiri atas karakteristik anak, karakteristik keluarga, kualitas lingkungan pengasuhan, kualitas pendidikan prasekolah, dan perkembangan kognitif anak. Data primer dikumpulkan dengan cara wawancara dan observasi.

Karakteristik anak meliputi jenis kelamin dan usia anak. Jenis kelamin anak terdiri atas lakilaki dan perempuan. Usia anak diukur berdasarkan bulan dengan ketentuan usia 1-15 hari dihitung sebagai usia 0 bulan dan usia 1631 hari dihitung sebagai usia 1 bulan. Anak yang dilibatkan dalam penelitian ini berusia 4265 bulan sampai dengan tanggal 15 April 2014. Berdasarkan usia, anak dikategorikan menjadi dua kelompok yaitu anak usia $42-53$ bulan dan 54-65 bulan.

Karakteristik keluarga terdiri atas pendidikan orang tua dan pendapatan keluarga. Pendidikan orang tua diukur berdasarkan jenjang pendidikan formal terakhir yang pernah diikuti dan lama pendidikan (dinyatakan dalam tahun). Pendapatan keluarga merupakan penjumlahan dari pendapatan seluruh anggota keluarga (ayah, ibu, dan anggota keluarga lain) yang dinyatakan dalam rupiah per bulan. Selanjutnya, pendapatan keluarga yang diperoleh dibagi dengan jumlah anggota keluarga untuk mendapatkan pendapatan keluarga per kapita (Rp/kapita/bulan).

Kualitas lingkungan pengasuhan diukur dengan skala Home Observation for Measurement of the Environment (HOME) yang disusun oleh Caldwell dan Bradley (2003). Instrumen ini terdiri atas delapan subskala yaitu ketersediaan bahan ajar (learning materials); stimulasi bahasa (language stimulation); lingkungan fisik (physical environment); sikap tanggap (responsivity); stimulasi akademik (academic stimulation); modeling (modeling); variasi stimulasi (variety); dan penerimaan (acceptance). Skala HOME terdiri atas 55 indikator dengan dua pilihan jawaban yaitu ya (skor 1) dan tidak (skor 0). Instrumen HOME telah reliabel dan valid dengan nilai Cronbach's alpha sebesar 0,900. Skor yang diperoleh dijumlahkan berdasarkan subskala (skor subskala) dan total (skor skala). Berdasarkan median, skor yang diperoleh dikategorikan menjadi dua kategori yaitu kurang baik (skor<median) dan baik (skor $\geq$ median).

Kualitas pendidikan prasekolah diukur berdasarkan sembilan komponen, yaitu rasio guru dan siswa, kualifikasi akademik guru, gaji guru, lingkungan fisik, kurikulum, penilaian kemajuan anak, stimulasi untuk perkembangan kognitif anak, interaksi di sekolah, dan partisipasi orang tua. Instrumen disusun berdasarkan Peraturan Menteri Pendidikan Nasional Republik Indonesia Nomor 58 tahun 2009 tentang Standar PAUD, instrumen akreditasi program PAUD, kriteria standar dan akreditasi Program PAUD National Association for the Education of Young Children (NAEYC, 2013), dan Quality Assessment Questionnaire (Olaleye, Florence, dan Omotayo, 2009). Indikator dalam pengukuran kualitas pendidikan prasekolah berjumlah 150 indikator, terdiri atas: satu indikator rasio guru-siswa, dua indikator kualifikasi akademik guru, satu indikator gaji guru, 55 indikator lingkungan fisik $(\alpha=0,963), 12$ indikator kurikulum $(\alpha=0,853)$, delapan indikator penilaian kemajuan anak $(\alpha=0,898), \quad 30$ indikator stimulasi untuk perkembangan kognitif $(\alpha=0,947), 36$ indikator interaksi di sekolah $(\alpha=0,913)$, dan lima indikator partisipasi orang tua $(\alpha=0,941)$. Setiap indikator memiliki dua pilihan jawaban yaitu ya (1) dan tidak (0). Skor yang diperoleh dijumlahkan, baik berdasarkan komponen maupun total. Selanjutnya, skor diubah dalam bentuk indeks dan dikategorikan menjadi tiga kategori yaitu rendah $(<60)$, sedang (60-80), dan tinggi (>80).

Perkembangan kognitif anak diukur menggunakan instrumen perkembangan kognitif yang disusun oleh Departemen Pendidikan Nasional (2004). Depdiknas (2004) menyusun instrumen perkembangan kognitif anak berdasarkan kelompok usia, yaitu instrumen perkembangan kognitif untuk anak usia 42-53 bulan dan untuk anak usia 54-65 bulan. Instrumen kognitif untuk anak usia 42-53 bulan terdiri atas 13 pertanyaan, tiga pilihan jawaban dengan skala 0-2, dan memiliki nilai Cronbach's alpha sebesar 0,812. Instrumen kognitif untuk anak usia 54-65 bulan terdiri atas 13 pertanyaan, empat pilihan jawaban dengan skala 0-3, memiliki nilai Cronbach's alpha sebesar 0,816. Skor yang diperoleh dijumlahkan dan selanjutnya skor tersebut diubah dalam bentuk indeks dan dikategorikan menjadi tiga kategori yaitu rendah $(<60)$, sedang (60-80), dan tinggi (>80).

Analisis data yang digunakan dalam penelitian ini adalah analisis deskriptif, uji beda $t$, dan analisis jalur. Analisis deskriptif untuk 
menghitung jumlah dan persentase dari kategori, nilai minimum, nilai maksimum, nilai rata-rata, dan standar deviasi dari setiap variabel penelitian. Uji beda $\mathrm{t}$ (independent samples t-test) untuk menganalisis perbedaan variabel penelitian berdasarkan pendidikan prasekolah formal dan nonformal. Variabel yang diuji dengan uji beda t adalah usia anak, pendidikan orang tua, pendapatan keluarga, kualitas lingkungan pengasuhan, kualitas pendidikan prasekolah, dan perkembangan kognitif anak. Analisis jalur untuk menganalisis pengaruh karakteristik anak, karakteristik keluarga, kualitas lingkungan pengasuhan, dan kualitas pendidikan prasekolah terhadap perkembangan kognitif anak.

\section{HASIL}

\section{Karakteristik Anak}

Anak yang terlibat dalam penelitian ini berjenis kelamin laki-laki (formal: 55,0\%, nonformal: $53,3 \%$ ) dan perempuan (formal: 45,0\%, nonformal: 46,7\%). Usia anak berkisar antara 42-65 bulan dengan usia rata-rata adalah 55,8 bulan (anak pendidikan prasekolah formal) dan 54,27 bulan (anak pendidikan prasekolah nonformal). Hasil uji beda menunjukkan bahwa tidak ada perbedaan yang signifikan $(p>0,05)$ antara usia anak berdasarkan jenis pendidikan prasekolah yang diikuti (formal dan nonformal).

\section{Karakteristik Keluarga}

Sebagian besar ayah dari anak yang mengikuti pendidikan prasekolah formal $(46,7 \%)$ dan nonformal $(65,0 \%)$ menamatkan pendidikan pada jenjang SMA/sederajat. Akan tetapi banyak juga ayah dari anak yang mengikuti pendidikan prasekolah formal yang menamatkan pendidikan pada jenjang perguruan tinggi (45,0\%). Rentang lama pendidikan ayah dari anak yang mengikuti pendidikan prasekolah formal adalah 6-21 tahun dengan rata-rata lama pendidikan adalah 13,5 tahun dan rentang lama pendidikan ayah dari anak yang mengikuti pendidikan prasekolah nonformal adalah 6-16 tahun dengan rata-rata lama pendidikan ayah adalah 11,7 tahun. Selanjutnya, sebagian besar ibu dari anak yang mengikuti pendidikan prasekolah formal telah menamatkan pendidikan pada jenjang SMA/sederajat $(43,3 \%)$ dan perguruan tinggi (48,3\%). Hasil penelitian juga menunjukkan bahwa ibu dari anak yang mengikuti pendidikan prasekolah nonformal telah menamatkan pendidikan pada jenjang SMA/sederajat (68,3\%). Rentang lama pendidikan ibu dari anak yang mengikuti pendidikan prasekolah formal adalah 6-18 tahun dengan rata-rata lama pendidikan adalah 13,5 tahun dan rentang lama pendidikan ibu dari anak yang mengikuti pendidikan prasekolah nonformal adalah 0-16 tahun dengan rata-rata lama pendidikan ibu adalah 11,7 tahun. Pendidikan ayah dan ibu dari anak pendidikan prasekolah formal dan nonformal berbeda signifikan $(p<0,01)$. Lama pendidikan ayah dan ibu dari anak pendidikan prasekolah formal lebih tinggi dibandingkan dengan pendidikan ayah dan ibu dari anak pendidikan prasekolah nonformal.

Hasil penelitian menunjukkan bahwa 76,7 persen keluarga dari anak pendidikan prasekolah formal memiliki pendapatan lebih dari Rp379.183,00/kapita/bulan, sedangkan 83,3 persen keluarga dari anak pendidikan prasekolah nonformal memiliki pendapatan kurang dari Rp379.183,00/kapita/bulan. Pendapatan keluarga per kapita per bulan antara anak yang mengikuti pendidikan prasekolah formal dengan anak yang mengikuti pendidikan prasekolah nonformal berbeda signifikan $(p<0,01)$. Rata-rata pendapatan keluarga dengan anak pendidikan prasekolah formal (Rp819.517,86/kapita/bulan) lebih tinggi dibandingkan dengan rata-rata pendapatan keluarga dengan anak pendidikan prasekolah nonformal (Rp337.441,68/kapita/bulan).

\section{Kualitas Lingkungan Pengasuhan}

Pengasuhan adalah pengalaman, keterampilan, kualitas, dan tanggung jawab sebagai orang tua dalam mendidik, merawat, dan mengasuh anak (Hoghughi, 2004). Dalam penelitian ini, kualitas lingkungan pengasuhan dilihat dari ketersediaan bahan ajar; stimulasi bahasa; lingkungan fisik; sikap tanggap; stimulasi akademik; modeling; variasi stimulasi; dan penerimaan (Caldwell \& Bradley, 2003). Sebaran contoh berdasarkan kualitas lingkungan pengasuhan disajikan pada Tabel 1.

Tabel 1 Sebaran contoh berdasarkan kualitas lingkungan pengasuhan

\begin{tabular}{|c|c|c|c|}
\hline Kategori & Formal & $\begin{array}{l}\text { Non- } \\
\text { formal }\end{array}$ & Total \\
\hline Kurang baik (skor<40) & 30,0 & 75,0 & 52,5 \\
\hline Baik (skor $\geq 40$ ) & 70,0 & 25,0 & 47,5 \\
\hline Total & 100,0 & 100,0 & 100,0 \\
\hline $\begin{array}{l}\text { Minimum-maksimum } \\
\text { (skor) }\end{array}$ & $28-51$ & $22-48$ & $22-51$ \\
\hline $\begin{array}{l}\text { Rata-rata } \pm \text { standar } \\
\text { deviasi (skor) }\end{array}$ & $\begin{array}{c}43,0 \pm \\
6,7\end{array}$ & $\begin{array}{c}34,5 \pm \\
5,9\end{array}$ & $\begin{array}{c}38,7 \pm \\
7,6\end{array}$ \\
\hline$p$-value & & $0,000^{* *}$ & \\
\hline
\end{tabular}

Keterangan: ${ }^{* *}$ signifikan pada $\mathrm{p}<0,01$ 
Berdasarkan hasil penelitian yang disajikan pada Tabel 1, orang tua dari anak pendidikan prasekolah formal dan nonformal menyediakan kualitas lingkungan pengasuhan yang berbeda $(p<0,01)$. Kualitas lingkungan pengasuhan yang disediakan oleh orang tua dari anak pendidikan prasekolah formal lebih baik dibandingkan dengan orang tua dari anak pendidikan prasekolah nonformal. Orang tua telah baik dalam pemberian stimulasi bahasa, sikap tanggap pada anak, dan pemberian contoh perilaku positif pada anak (modeling). Akan tetapi, orang tua masih kurang baik dalam hal penyediaan bahan ajar, lingkungan fisik, stimulasi akademik, variasi stimulasi, dan penerimaan (Elmanora, Hastuti, \& Muflikhati, 2015).

Tujuh dari sepuluh orang tua pendidikan prasekolah formal mampu menyediakan lingkungan pengasuhan yang berkualitas baik untuk anaknya. Orang tua pendidikan prasekolah formal telah baik dalam menyediakan bahan ajar yang dapat membantu anak dalam belajar, memberikan stimulasi bahasa, menyediakan lingkungan fisik, menunjukkan sikap tanggap pada anak, dan mencontohkan perilaku positif pada anak (modeling), namun orang tua masih kurang baik dalam memberikan stimulasi akademik, memberikan stimulasi yang bervariasi, dan menerima anak.

Tiga dari empat orang tua pendidikan prasekolah nonformal menyediakan kualitas lingkungan pengasuhan yang kurang baik untuk anaknya terutama dalam menyediakan bahan ajar yang dapat digunakan anak untuk belajar, menyediakan lingkungan fisik yang kondusif untuk belajar dan bermain anak, memberikan stimulasi dengan teknik yang bervariasi, dan menerima anak. Kualitas lingkungan pengasuhan yang telah disediakan dengan baik oleh orang tua dari anak pendidikan prasekolah nonformal adalah pemberian stimulasi bahasa, sikap tanggap pada anak, dan pemberian contoh perilaku positif pada anak (modeling).

\section{Kualitas Pendidikan Prasekolah}

Kualitas pendidikan prasekolah diukur berdasarkan sembilan komponen, yaitu rasio guru dan siswa, kualifikasi akademik guru, gaji guru, lingkungan fisik, kurikulum, penilaian kemajuan anak, stimulasi untuk perkembangan kognitif anak, interaksi di sekolah, dan partisipasi orang tua. Kualitas pendidikan prasekolah formal (75,0\%) termasuk dalam kategori tinggi, sedangkan kualitas pendidikan prasekolah nonformal $(50,0 \%)$ termasuk dalam kategori rendah.
Tabel 2 Sebaran contoh berdasarkan kategori perkembangan kognitif anak

\begin{tabular}{lrrr}
\hline Kategori & \multicolumn{1}{c}{ Formal } & $\begin{array}{c}\text { Non- } \\
\text { formal }\end{array}$ & \multicolumn{1}{c}{ Total } \\
\hline Rendah & 0,0 & 30,0 & 15,0 \\
Sedang & 33,3 & 63,3 & 48,3 \\
Tinggi & 66,7 & 6,7 & 36,7 \\
\hline Total & 100,0 & 100,0 & 100,0 \\
Minimum- & $61,5-97,4$ & $42,3-94,9$ & $42,3-97,4$ \\
maksimum & & & \\
(skor) & & & \\
Rata-rata \pm & $84,2 \pm 10,4$ & $67,5 \pm 13,7$ & $75,9 \pm 14,8$ \\
standar & & & \\
deviasi (skor) & & $0,000^{* *}$ \\
$p$-value & \multicolumn{3}{|}{} \\
\hline Keterangan: ${ }^{*}$ Signifikan pada $p<0,01$
\end{tabular}

Berdasarkan hasil penelitian, kualitas pendidikan prasekolah formal dan nonformal berbeda signifikan $(p<0,01)$. Rata-rata indeks kualitas pendidikan prasekolah formal lebih tinggi dibandingkan dengan rata-rata indeks kualitas pendidikan prasekolah nonformal. Kualitas pendidikan prasekolah baik formal atau nonformal masih belum optimal pada komponen rasio guru-siswa, kualifikasi akademik guru, gaji guru, lingkungan fisik, kurikulum, stimulasi untuk perkembangan kognitif, dan partisipasi orang tua dalam kegiatan pendidikan prasekolah. Selain itu, pendidikan prasekolah nonformal juga belum optimal dalam menjalankan komponen penilaian kemajuan anak dan interaksi di sekolah.

\section{Tingkat Perkembangan Kognitif Anak}

Perkembangan kognitif anak pendidikan prasekolah formal $(66,7 \%)$ termasuk dalam kategori tinggi, sedangkan perkembangan kognitif anak pendidikan prasekolah nonformal $(63,3 \%)$ termasuk dalam kategori sedang (Tabel 2). Perkembangan kognitif anak prasekolah formal lebih baik dibandingkan dengan anak prasekolah nonformal $(p=0,000)$.

Pengaruh Karakteristik Anak, Karakteristik Keluarga, Kualitas Lingkungan Pengasuhan, dan Kualitas Pendidikan Prasekolah terhadap Perkembangan Kognitif Anak Pendidikan Prasekolah

\footnotetext{
Analisis Jalur untuk Perkembangan Kognitif Anak Pendidikan Prasekolah Formal. Hasil analisis jalur untuk menganalisis pengaruh karakteristik anak, karakteristik keluarga, kualitas lingkungan pengasuhan, dan kualitas pendidikan prasekolah terhadap perkembangan kognitif anak pendidikan prasekolah formal disajikan pada Gambar 1.
} 


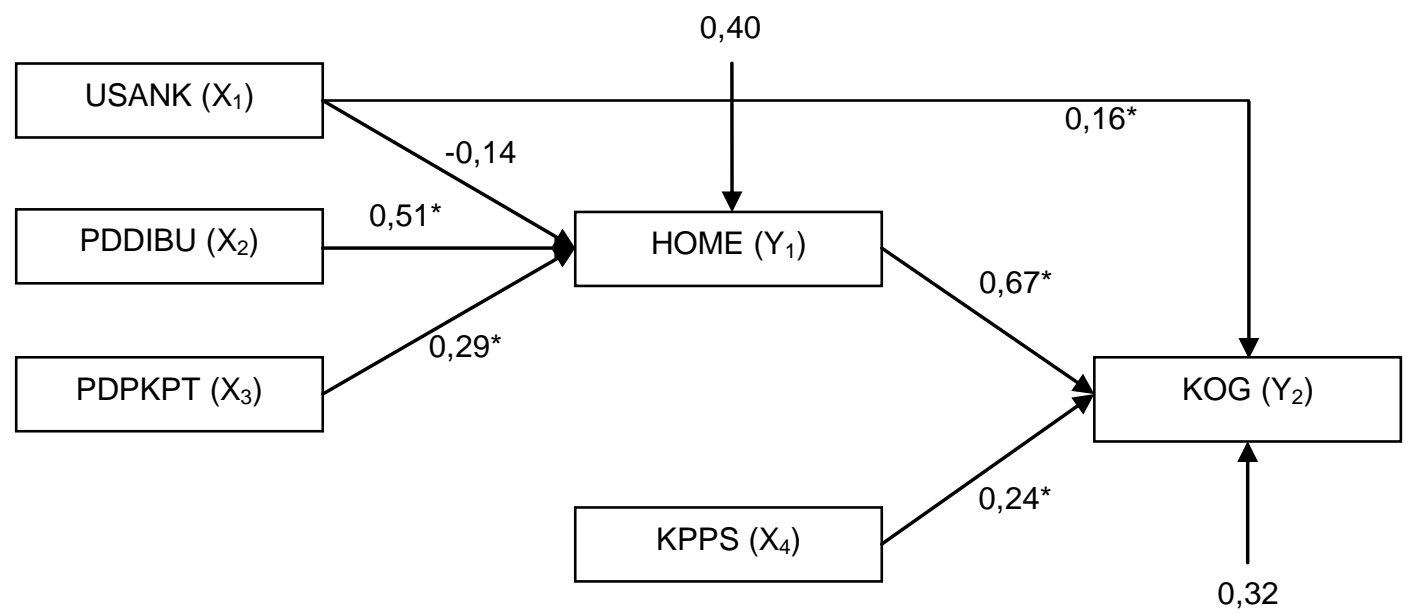

\begin{tabular}{|lll|}
\hline Keterangan: & & \\
USANK & $:$ & Usia anak (bulan) \\
PDDIBU & $:$ & Lama pendidikan ibu (tahun) \\
PDPKPT & $:$ & Pendapatan keluarga (Rp/kapita/bulan) \\
HOME & $:$ & Kualitas lingkungan pengasuhan (skor) \\
KPPS & $:$ & Kualitas pendidikan prasekolah formal (indeks) \\
KOG & $:$ & Perkembangan kognitif anak (indeks) \\
\hline
\end{tabular}

\begin{tabular}{|lll|}
\hline \multicolumn{3}{|l|}{ Goodness of Fit (GOF) } \\
$\mathrm{N}$ & $:$ & 60 \\
$\mathrm{Df}$ & $:$ & 3 \\
$X^{2}$ & $:$ & 15,76 \\
$\mathrm{RMSEA}$ & $:$ & 0,28 \\
$\mathrm{GFI}$ & $:$ & 0,92 \\
$\mathrm{NFI}$ & $:$ & 0,93 \\
$\mathrm{IFI}$ & $:$ & 0,94 \\
$\mathrm{CFI}$ & $:$ & 0,94 \\
\hline
\end{tabular}

Gambar 1 Hasil analisis jalur untuk perkembangan kognitif anak pendidikan prasekolah formal

Model dari analisis jalur untuk perkembangan kognitif anak pendidikan prasekolah formal memiliki koefisien determinasi $\left(R^{2}\right)$ sebesar 0,46 . Hasil ini mengindikasikan bahwa variasi variabel dalam model yang telah disusun (usia anak, pendidikan ibu, pendapatan keluarga, kualitas lingkungan pengasuhan, dan kualitas pendidikan prasekolah) dapat menerangkan 46,0 persen variasi perkembangan kognitif anak pendidikan prasekolah formal. Hasil penghitungan koefisien struktural dan nilai $t$ untuk perkembangan kognitif anak pendidikan prasekolah formal disajikan pada Tabel 3.

Perkembangan kognitif anak pendidikan prasekolah formal secara tidak langsung dipengaruhi oleh pendidikan ibu (koef. $=0,34$, $t>1,96$ ). Penambahan lama pendidikan ibu sebesar satu satuan dapat meningkatkan perkembangan kognitif anak pendidikan prasekolah formal sebesar 0,34 satuan. Perkembangan kognitif anak pendidikan prasekolah formal secara tidak langsung juga dipengaruhi oleh pendapatan keluarga (koef. $=0,19, t>1,96)$. Penambahan pendapatan keluarga sebesar satu satuan dapat meningkatkan perkembangan kognitif anak pendidikan prasekolah formal sebesar 0,19 satuan. Pendidikan ibu dan pendapatan keluarga berpengaruh pada perkembangan kognitif melalui kualitas lingkungan pengasuhan.

Tabel 3 Nilai koefisien struktural dan nilai t analisis jalur untuk perkembangan kognitif anak pendidikan prasekolah formal

\begin{tabular}{|c|c|c|c|c|c|}
\hline No & Variabel & $\begin{array}{l}\text { Pengaruh } \\
\text { langsung }\end{array}$ & $\begin{array}{c}\text { Pengaruh tidak } \\
\text { langsung melalui } \\
\text { kualitas lingkungan } \\
\text { pengasuhan }\end{array}$ & Pengaruh total & Nilai $t$ \\
\hline 1 & Usia anak (bulan) & 0,16 & $-0,09$ & 0,07 & 0,67 \\
\hline 2 & Pendidikan ibu (tahun) & - & 0,34 & $0,34^{*}$ & 3,86 \\
\hline 3 & $\begin{array}{l}\text { Pendapatan keluarga } \\
\text { (Rp/kapita/bulan) }\end{array}$ & - & 0,19 & $0,19^{*}$ & 2,36 \\
\hline 4 & $\begin{array}{l}\text { Kualitas lingkungan } \\
\text { pengasuhan (skor) }\end{array}$ & 0,67 & - & $0,67^{*}$ & 7,84 \\
\hline \multirow[t]{2}{*}{5} & $\begin{array}{l}\text { Kualitas pendidikan } \\
\text { prasekolah (indeks) }\end{array}$ & 0,24 & - & $0,24^{*}$ & 2,84 \\
\hline & Koefisien determinasi $\left(\mathrm{R}^{2}\right)$ & & 0,46 & & \\
\hline
\end{tabular}




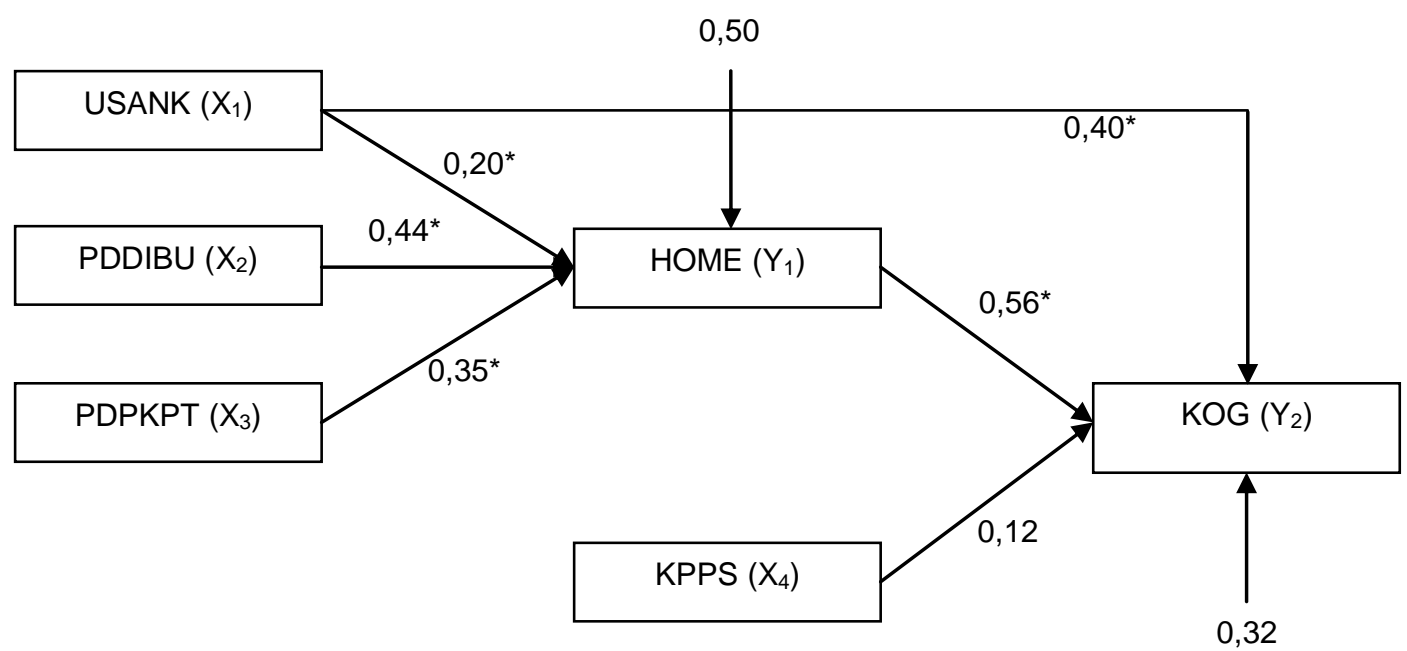

\begin{tabular}{|lll|}
\hline Keterangan: & & \\
USANK & $:$ & Usia anak (bulan) \\
PDDIBU & $:$ & Lama pendidikan ibu (tahun) \\
PDPKPT & $\vdots$ & Pendapatan keluarga (Rp/kapita/bulan) \\
HOME & $\vdots$ & Kualitas lingkungan pengasuhan (skor) \\
KPPS & $\vdots$ & Kualitas pendidikan prasekolah nonformal (indeks) \\
KOG & $:$ & Perkembangan kognitif anak (indeks) \\
\hline
\end{tabular}

\begin{tabular}{|lcl|}
\hline \multicolumn{3}{l|}{ Goodness of Fit (GOF) } \\
N & $\vdots$ & 60 \\
Df & $\vdots$ & 3 \\
$X^{2}$ & $\vdots$ & 15,17 \\
RMSEA & $\vdots$ & 0,27 \\
GFI & $:$ & 0,92 \\
NFI & $:$ & 0,90 \\
IFI & $:$ & 0,91 \\
\hline
\end{tabular}

Gambar 2 Hasil analisis jalur untuk perkembangan kognitif anak pendidikan prasekolah nonformal

\begin{tabular}{|c|c|}
\hline 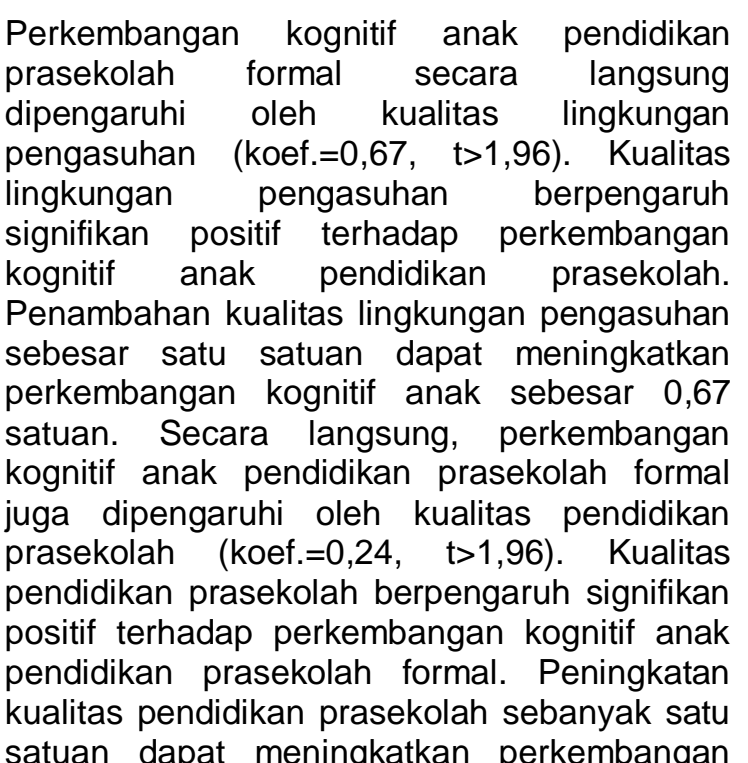 & $\begin{array}{l}\text { kognitif anak sebanyak } 0,26 \text { satuan. Hasil } \\
\text { analisis juga menemukan bahwa besaran } \\
\text { pengaruh stimulasi dari lingkungan keluarga } \\
\text { yang dinilai dari kualitas lingkungan } \\
\text { pengasuhan lebih besar dibandingkan dengan } \\
\text { besaran pengaruh stimulasi dari lingkungan } \\
\text { sekolah yang dinilai dari kualitas pendidikan } \\
\text { prasekolah. Dengan demikian, keluarga } \\
\text { memiliki peranan yang besar dalam } \\
\text { mengoptimalkan perkembangan kognitif anak } \\
\text { pendidikan prasekolah formal. Meskipun } \\
\text { pengaruh dari lingkungan sekolah lebih kecil } \\
\text { dibandingkan pengaruh dari lingkungan } \\
\text { keluarga, keikutsertaan anak pada pendidikan } \\
\text { prasekolah formal yang berkualitas tetap } \\
\text { penting karena kualitas pendidikan prasekolah } \\
\text { merupakan salah satu faktor penentu } \\
\text { optimalnya perkembangan kognitif anak } \\
\text { pendidikan prasekolah formal. }\end{array}$ \\
\hline
\end{tabular}

Tabel 4 Nilai koefisien struktural dan nilai t analisis jalur untuk perkembangan kognitif anak pendidikan prasekolah nonformal

\begin{tabular}{|c|c|c|c|c|}
\hline Variabel & $\begin{array}{l}\text { Pengaruh } \\
\text { langsung }\end{array}$ & $\begin{array}{l}\text { Pengaruh tidak langsung melalui } \\
\text { kualitas lingkungan pengasuhan }\end{array}$ & $\begin{array}{l}\text { Pengaruh } \\
\text { total }\end{array}$ & Nilai t \\
\hline Usia anak (bulan) & 0,40 & 0,11 & $0,51^{*}$ & 5,43 \\
\hline Pendidikan ibu (tahun) & - & 0,25 & $0,25^{*}$ & 3,53 \\
\hline $\begin{array}{l}\text { Pendapatan keluarga } \\
\text { (Rp/kapita/bulan) }\end{array}$ & - & 0,20 & $0,20^{*}$ & 2,97 \\
\hline $\begin{array}{l}\text { Kualitas lingkungan } \\
\text { pengasuhan (skor) }\end{array}$ & 0,56 & - & $0,56^{*}$ & 6,80 \\
\hline $\begin{array}{l}\text { Kualitas pendidikan } \\
\text { prasekolah (indeks) }\end{array}$ & 0,12 & - & 0,12 & 1,49 \\
\hline
\end{tabular}

Koefisien determinasi $\left(\mathrm{R}^{2}\right)$

Keterangan: * Signifikan pada nilai $\mathrm{t}>1,96$ 


\section{Analisis Jalur untuk Perkembangan Kognitif Anak Pendidikan Prasekolah Nonformal.} Hasil analisis jalur untuk menganalisis pengaruh karakteristik anak, karakteristik keluarga, kualitas lingkungan pengasuhan, dan kualitas pendidikan prasekolah terhadap perkembangan kognitif anak pendidikan prasekolah nonformal disajikan pada Gambar 2. Model analisis jalur untuk perkembangan kognitif anak pendidikan prasekolah nonformal memiliki koefisien determinasi $\left(R^{2}\right)$ sebesar 0,50 yang mengindikasikan bahwa variasi variabel dalam model (usia anak, pendidikan ibu, pendapatan keluarga, kualitas lingkungan pengasuhan, dan kualitas pendidikan prasekolah) dapat menerangkan 50,0 persen variasi perkembangan kognitif anak pendidikan prasekolah nonformal (Tabel 4).

Usia anak secara langsung dan tidak langsung (melalui kualitas lingkungan pengasuhan) berpengaruh signifikan terhadap perkembangan kognitif anak pendidikan prasekolah nonformal (koef. $=0,51, \quad t>1,96$ ).
Penambahan usia dapat meningkatkan perkembangan kognitif anak pendidikan prasekolah nonformal. Perkembangan kognitif anak pendidikan prasekolah nonformal secara tidak langsung dipengaruhi oleh pendidikan ibu (koef. $=0,25, \quad t>1,96$ ). Penambahan lama pendidikan ibu sebesar satu satuan dapat meningkatkan perkembangan kognitif anak pendidikan prasekolah formal sebesar 0,25 satuan. Perkembangan kognitif anak pendidikan prasekolah nonformal secara tidak langsung juga dipengaruhi oleh pendapatan keluarga (koef. $=0,20, t>1,96$ ). Penambahan pendapatan keluarga sebesar satu satuan dapat meningkatkan perkembangan kognitif anak pendidikan prasekolah formal sebesar 0,20 satuan. Pendidikan ibu dan pendapatan keluarga berpengaruh terhadap perkembangan kognitif anak pendidikan prasekolah nonformal melalui kualitas lingkungan pengasuhan. Keluarga dengan ibu yang berpendidikan tinggi dan berpenghasilan besar mampu menyediakan lingkungan pengasuhan dengan kualitas yang baik.

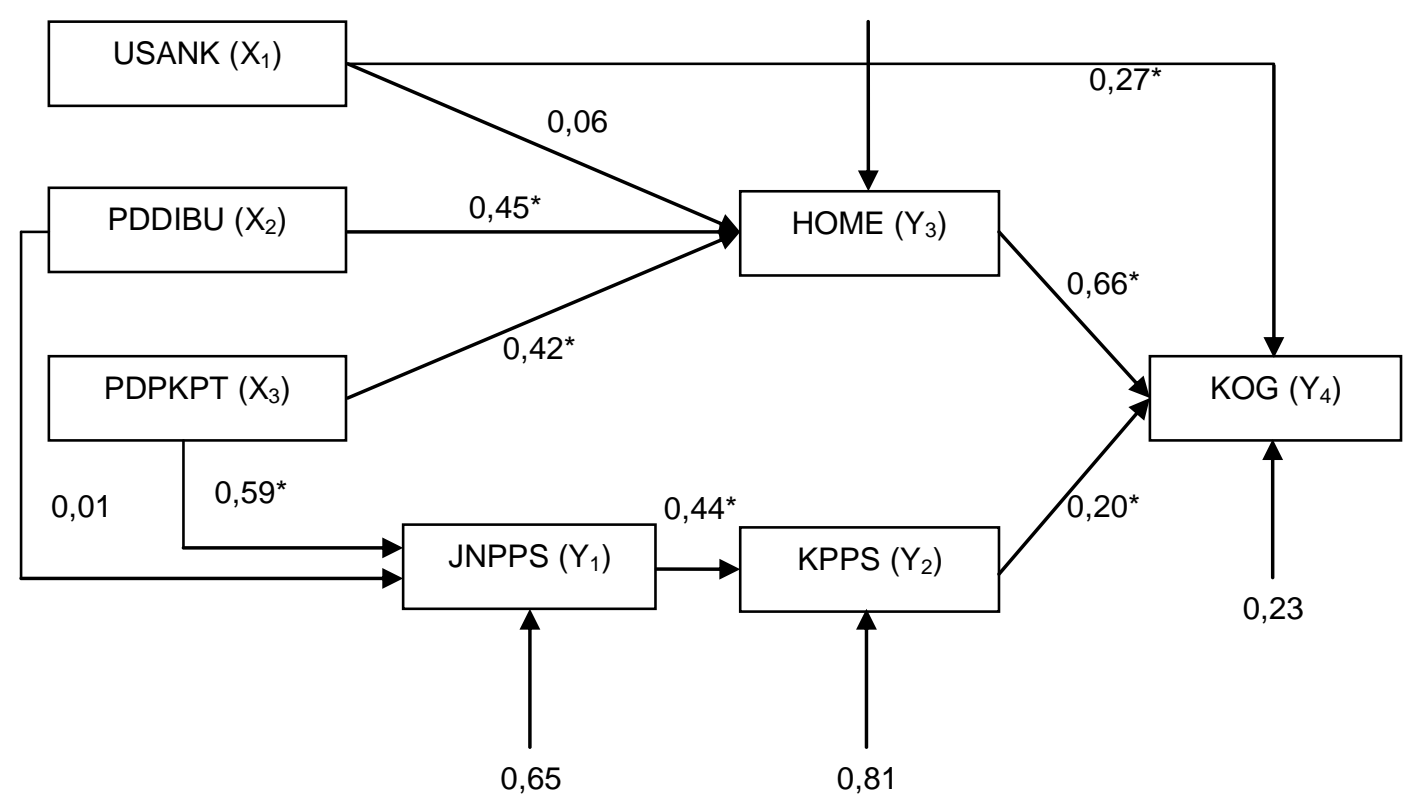

\begin{tabular}{|c|c|c|c|}
\hline \multicolumn{2}{|l|}{ Keterangan: } & \multicolumn{2}{|c|}{ Goodness of Fit (GOF) } \\
\hline USANK & : Usia anak (bulan) & $\mathrm{N}$ & $: 120$ \\
\hline PDDIBU & Lama pendidikan ibu (tahun) & Df & 9 \\
\hline PDPKPT & Pendapatan keluarga (Rp/kapita/bulan) & $X^{2}$ & 68.91 \\
\hline JNPPS & Jenis pendidikan prasekolah (0: nonformal, 1 : formal) & RMSEA & $: \quad 0,24$ \\
\hline HOME & Kualitas lingkungan pengasuhan (skor) & GFI & 0,86 \\
\hline KPPS & : Kualitas pendidikan prasekolah formal dan nonformal (indeks) & NFI & 0,86 \\
\hline KOG & : $\quad$ Perkembangan kognitif anak (indeks) & IFI & $: \quad 0,87$ \\
\hline & & CFI & $: \quad 0,87$ \\
\hline
\end{tabular}

Gambar 3 Hasil analisis jalur untuk perkembangan kognitif anak pendidikan prasekolah formal dan nonformal 
Tabel 5 Nilai koefisien struktural dan nilai t analisis jalur untuk perkembangan kognitif anak pendidikan prasekolah formal dan nonformal

\begin{tabular}{|c|c|c|c|c|c|c|}
\hline \multirow[b]{2}{*}{ No } & \multirow[b]{2}{*}{ Variabel } & \multirow[b]{2}{*}{$\begin{array}{l}\text { Pengaruh } \\
\text { langsung }\end{array}$} & \multicolumn{2}{|c|}{ Pengaruh tidak langsung } & \multirow[b]{2}{*}{$\begin{array}{l}\text { Pengaruh } \\
\text { total }\end{array}$} & \multirow[b]{2}{*}{ Nilai $t$} \\
\hline & & & $\begin{array}{c}\text { Kualitas } \\
\text { lingkungan } \\
\text { pengasuhan }\end{array}$ & $\begin{array}{l}\text { Kualitas } \\
\text { pendidikan } \\
\text { prasekolah }\end{array}$ & & \\
\hline 1 & Usia anak (bulan) & 0,27 & 0,04 & - & $0,31^{*}$ & 5,36 \\
\hline 2 & $\begin{array}{l}\text { Pendidikan ibu } \\
\text { (tahun) }\end{array}$ & - & 0,30 & 0,00 & $0,30^{*}$ & 5,62 \\
\hline 3 & $\begin{array}{l}\text { Pendapatan keluarga } \\
\text { (Rp/kapita/bulan) }\end{array}$ & - & 0,28 & 0,05 & $0,33^{*}$ & 6,08 \\
\hline 4 & $\begin{array}{l}\text { Kualitas lingkungan } \\
\text { pengasuhan (skor) }\end{array}$ & 0,66 & - & - & $0,66^{*}$ & 14,40 \\
\hline 5 & $\begin{array}{l}\text { Jenis pendidikan } \\
\text { prasekolah ( } 0 \text { : } \\
\text { nonformal, } 1 \text { : formal) }\end{array}$ & - & - & 0,09 & $0,09^{*}$ & 3,34 \\
\hline \multirow[t]{2}{*}{6} & $\begin{array}{l}\text { Kualitas pendidikan } \\
\text { prasekolah (indeks) }\end{array}$ & 0,20 & - & - & $0,20^{*}$ & 4,35 \\
\hline & $\begin{array}{l}\text { Koefisien determinasi } \\
\left(R^{2}\right)\end{array}$ & & & 0,49 & & \\
\hline
\end{tabular}

Secara langsung, perkembangan kognitif anak pendidikan prasekolah formal dipengaruhi oleh kualitas lingkungan pengasuhan (koef. $=0,56$, $t>1,96$ ). Kualitas lingkungan pengasuhan berpengaruh signifikan positif terhadap perkembangan kognitif anak pendidikan prasekolah. Penambahan kualitas lingkungan pengasuhan sebesar satu satuan dapat meningkatkan perkembangan kognitif anak sebesar 0,56 satuan. Kualitas pendidikan prasekolah tidak berpengaruh signifikan positif terhadap perkembangan kognitif anak pendidikan prasekolah nonformal $(\mathrm{t}>1,96)$. Dengan demikian, penentu perkembangan kognitif anak pendidikan prasekolah nonformal adalah lingkungan keluarga. Kualitas pendidikan prasekolah nonformal yang tidak berpengaruh signifikan terhadap perkembangan kognitif anak disebabkan oleh tidak adanya lembaga pendidikan prasekolah nonformal yang berkualitas tinggi. Kualitas pendidikan prasekolah nonformal termasuk dalam kategori rendah dan sedang. Oleh karenanya, perbaikan kualitas pendidikan prasekolah diperlukan untuk meningkatkan kualitas pendidikan prasekolah sehingga pendidikan prasekolah tersebut dapat membantu dalam memberikan stimulasi untuk mencapai perkembangan yang optimal.

Analisis Jalur untuk Perkembangan Kognitif Anak Pendidikan Prasekolah. Hasil analisis jalur untuk perkembangan kognitif anak pendidikan prasekolah formal dan nonformal disajikan pada Gambar 3. Model analisis jalur untuk menganalisis pengaruh karakteristik anak, karakteristik keluarga, kualitas lingkungan pengasuhan, dan kualitas pendidikan prasekolah terhadap perkembangan kognitif anak pendidikan prasekolah formal dan nonformal memiliki koefisien determinasi $\left(R^{2}\right)$ sebesar 0,49. Hasil ini mengindikasikan bahwa variasi variabel dalam model (usia anak, pendidikan ibu, pendapatan keluarga, kualitas lingkungan pengasuhan, jenis pendidikan prasekolah, dan kualitas pendidikan prasekolah) dapat menerangkan 49,0 persen variasi perkembangan kognitif anak pendidikan prasekolah formal dan nonformal. Hasil penelitian yang disajikan pada Tabel 5 menunjukkan bahwa perkembangan kognitif anak pendidikan prasekolah secara signifikan dipengaruhi oleh usia anak (koef. $=0,31, t>1,96$ ), pendidikan ibu (koef. $=0,30, \quad \mathrm{t}>1,96)$, pendapatan keluarga (koef. $=0,33, \quad t>1,96$ ), kualitas lingkungan pengasuhan (koef. $=0,66$, $t>1,96)$, jenis pendidikan prasekolah (koef. $=0,09, t>1,96$ ), dan kualitas pendidikan prasekolah (koef. $=0,20, t>1,96$ ).

\section{PEMBAHASAN}

Perkembangan kognitif anak ditentukan oleh stimulasi dari lingkungan keluarga dan lingkungan sekolah. Temuan ini menguatkan teori Ekologi Bronfenbrenner bahwa keluarga dan sekolah yang merupakan bagian dari lingkungan mikrosistem menentukan perkembangan anak. Berdasarkan besaran pengaruhnya, lingkungan keluarga lebih berperan dalam menentukan perkembangan kognitif anak dibandingkan dengan lingkungan sekolah. Hasil ini menguatkan temuan sebelumnya bahwa lingkungan pengasuhan 
sebagai penentu utama perkembangan kognitif anak usia prasekolah (Andrade et al., 2005; Camargo-Figuera, 2014). Hal ini dapat terjadi karena orang tua merupakan guru pertama yang berperan penting dalam pembelajaran anak. Meskipun lingkungan pengasuhan memiliki pengaruh yang lebih besar, kualitas pendidikan prasekolah juga berperan penting untuk membantu keluarga dalam mencapai perkembangan kognitif anak yang optimal terutama pada keluarga dengan lingkungan pengasuhan yang berkualitas rendah. Oleh sebab itu, perbaikan pada kualitas lingkungan pengasuhan dan kualitas pendidikan prasekolah diperlukan sebagai upaya dalam mengoptimalkan perkembangan kognitif anak pendidikan prasekolah.

Perkembangan kognitif anak pendidikan prasekolah secara signifikan dipengaruhi oleh usia anak (koef. $=0,31, \mathrm{t}>1,96)$, pendidikan ibu (koef. $=0,30, \quad t>1,96)$, pendapatan keluarga (koef. $=0,33, \quad t>1,96)$, kualitas lingkungan pengasuhan (koef. $=0,66, \quad t>1,96)$, jenis pendidikan prasekolah (koef. $=0,09, \mathrm{t}>1,96$ ), dan kualitas pendidikan prasekolah (koef. $=0,20$, $t>1,96)$. Usia anak berpengaruh signifikan positif terhadap perkembangan kognitif anak yang mengindikasikan bahwa penambahan usia anak dapat meningkatkan perkembangan kognitif anak. Menurut Holden (2010), penambahan usia pada anak menyebabkan terjadinya beberapa perubahan pada anak tersebut, diantaranya adalah perubahan fisik anak, perubahan pada kemampuan kognitif dan bahasa, serta perubahan dalam kematangan emosi dan keterampilan sosial. Perubahanperubahan tersebut berdampak pada perkembangan kognitif anak. Papalia, Old, dan Feldman (2008) mengungkapkan bahwa pertumbuhan fisik dan kematangan sosial emosi berkaitan erat dengan kemajuan kognitif. Dengan demikian, peningkatan perkembangan fisik melalui pertumbuhan fisik dan perkembangan sosial emosi yang ditandai dengan kematangan sosial emosi mendorong terjadinya peningkatan pada perkembangan kognitif. Hasil penelitian ini juga menguatkan model yang disusun oleh Belsky yaitu Determinants of Parenting (Holden, 2010). Usia anak yang merupakan bagian dari karakteristik anak menjadi faktor yang berpengaruh langsung pada perkembangan anak.

Pendidikan ibu dan pendapatan keluarga berpengaruh signifikan positif terhadap perkembangan kognitif anak. Pengaruh dari pendidikan dan pendapatan keluarga terhadap perkembangan kognitif anak terjadi secara tidak langsung yaitu melalui kualitas lingkungan pengasuhan. Hasil ini sejalan dengan DavisKean (2005) yang menyebutkan bahwa pendidikan ibu dan pendapatan keluarga berpengaruh pada perkembangan anak melalui lingkungan pengasuhan. Pendidikan ibu dan pendapatan keluarga menjadi faktor penting yang menentukan kualitas lingkungan fisik dan pengalaman belajar pada anak (Klebanov, Brooks-Gunn, \& Duncan, 1994). Ibu yang berpendidikan tinggi dan memiliki pendapatan keluarga yang besar mampu menyediakan lingkungan fisik rumah yang berkualitas. Hal ini dapat terjadi karena pendidikan dan pendapatan memengaruhi keluarga dalam hal pemilihan lokasi, ukuran, penataan, serta perkakas. Pendidikan yang tinggi dan pendapatan yang besar juga memungkinkan keluarga untuk menyediakan media stimulasi seperti mainan dan buku yang dapat digunakan untuk memberikan pengalaman belajar pada anak.

Pendapatan keluarga yang rendah menyebabkan keluarga menjadi tidak sejahtera. Kesejahteraan keluarga juga erat kaitannya dengan pengasuhan karena ketidaksejahteraan dapat menghambat keluarga dalam menyediakan lingkungan pengasuhan yang berkualitas. Hasil ini konsisten dengan hasil penelitian yang telah dilakukan sebelumnya bahwa ketidaksejahteraan keluarga menjadi salah satu penyebab rendahnya kualitas lingkungan pengasuhan (Klebanov, Brooks-Gunn, \& Duncan, 1994; Pachter et al., 2006; Zevalkink, Riksen-Walraven, \& Bradley, 2008). Ketidaksejahteraan dapat menghambat keluarga dalam menyediakan sumber daya baik sumber daya fisik maupun psikososial. Selain itu, ketidaksejahteraan keluarga juga menyebabkan keluarga tidak mampu menyediakan fasilitas yang memadai untuk anak belajar dan bermain (Eamon, 2001).

Menurut Kiernan dan Huerta (2008), pengasuhan menjadi perantara pada pengaruh ketidaksejahteraan keluarga terhadap perkembangan kognitif anak. Dearing dan Taylor (2007) menjelaskan bahwa keluarga tidak sejahtera memiliki sumber daya yang lebih sedikit sehingga stimulasi yang dapat diterima anak juga menjadi sedikit. Selanjutnya, keluarga yang tidak sejahtera juga cenderung menerapkan pengasuhan yang negatif. Penyediaan stimulasi yang sedikit berdampak pada tidak optimalnya perkembangan anak. Anak yang hidup dalam keluarga tidak sejahtera lebih beresiko untuk mengalami masalah perkembangan anak terutama perkembangan kognitif (Aber et al., 1997; Harden \& Whittaker, 2011). Welsch dan 
Zimmer (2010) juga menegaskan bahwa ketidaksejahteraan keluarga menjadi salah satu faktor yang berpengaruh pada perkembangan kognitif anak di usia awal. Dengan demikian, pendapatan keluarga yang rendah berdampak pada rendahnya kualitas lingkungan pengasuhan dan pada akhirnya berdampak pada tidak optimalnya perkembangan kognitif anak.

Kualitas lingkungan pengasuhan berpengaruh secara langsung dan pengaruhnya signifikan positif terhadap perkembangan kognitif anak. Hasil ini menegaskan bahwa peningkatan kualitas lingkungan pengasuhan dapat meningkatkan perkembangan kognitif anak. Hal ini dapat terjadi karena lingkungan pengasuhan berkaitan dengan penyediaan dan pemberian stimulasi untuk perkembangan anak. Stimulasi yang diberikan dalam pengasuhan semakin banyak dengan semakin berkualitasnya lingkungan pengasuhan. Stimulasi yang diberikan ini dapat digunakan untuk meningkatkan perkembangan kognitif anak. Contohnya adalah anak yang diajarkan tentang warna melalui mainan oleh orang tuanya mampu menyebutkan nama-nama warna dan menjodohkan warna dengan benar. Anak belajar dari stimulasi yang diberikan oleh orang tuanya. Misalnya, anak belajar tentang menyusun pola setelah mendapatkan mainan berupa puzzle. Oleh karenanya, lingkungan pengasuhan yang berkualitas dapat meningkatkan perkembangan kognitif anak. Hasil penelitian ini menguatkan hasil penelitian sebelumnya, di antaranya adalah Rahmaulina dan Hastuti (2008), Lugo-Gil dan TamisLeMonda (2008), Hastuti (2009), dan Hastuti, Alfiasari, Chandriyani (2010), serta Tucker-Drob dan Harden (2011). Kualitas lingkungan pengasuhan yang diistilahkan dengan stimulasi psikososial berhubungan signifikan positif dengan perkembangan kognitif anak (Rahmaulina \& Hastuti, 2008) dan berpengaruh signifikan positif pada perkembangan kognitif anak (Hastuti, 2009; Hastuti, Alfiasari, Chandriyani, 2010). Kualitas pengasuhan berkontribusi dalam membentuk perkembangan kognitif anak (Lugo-Gil \& Tamis-LeMonda, 2008). Temuan utama dari penelitian TuckerDrob dan Harden (2011) juga menunjukkan perilaku orang tua sebagai penentu utama kemampuan anak sehingga pemberian stimulasi kognitif oleh orang tua melalui pengasuhan dapat meningkatkan perkembangan kognitif anak.

Perkembangan kognitif anak dipengaruhi juga oleh jenis dan kualitas pendidikan prasekolah. Hasil ini mengindikasikan peningkatan kualitas pendidikan prasekolah dapat meningkatkan perkembangan kognitif anak. Pendidikan prasekolah yang berkualitas mampu memberikan banyak stimulasi untuk perkembangan kognitif anak. Hasil penelitian ini menguatkan hasil penelitian sebelumnya bahwa anak yang mengikuti pendidikan prasekolah yang berkualitas memiliki perkembangan kognitif yang lebih baik dibandingkan dengan anak yang mengikuti pendidikan prasekolah tidak berkualitas (Barnett, 1995; Barnett \& Ackerman, 2006; Rao, 2010; Anders et al., 2012). Pendidikan prasekolah yang berkualitas mampu meningkatkan perkembangan kognitif anak yang dapat dirasakan baik dalam jangka pendek maupun jangka panjang (fBurger, 2010; Camili et al., 2011).

\section{SIMPULAN DAN SARAN}

Keluarga dengan anak yang mengikuti pendidikan prasekolah formal memiliki pendidikan ibu, pendapatan keluarga per kapita per bulan, dan kualitas lingkungan pengasuhan yang lebih tinggi dibandingkan keluarga dengan anak yang mengikuti pendidikan prasekolah nonformal. Kualitas pendidikan prasekolah formal juga lebih baik dibandingkan kualitas pendidikan prasekolah nonformal. Perkembangan kognitif anak dipengaruhi oleh usia anak, pendidikan ibu, pendapatan keluarga, kualitas lingkungan pengasuhan, jenis pendidikan prasekolah, dan kualitas pendidikan prasekolah. Berdasarkan hasil analisis jalur, stimulasi dari lingkungan keluarga memiliki pengaruh yang lebih kuat pada perkembangan kognitif anak dibandingkan dengan stimulasi dari lingkungan sekolah. Hal ini dapat terjadi karena orang tua merupakan guru pertama yang berperan penting dalam pembelajaran anak. Meskipun lingkungan pengasuhan memiliki pengaruh yang lebih besar, kualitas pendidikan prasekolah juga berperan penting untuk membantu keluarga dalam mencapai perkembangan kognitif anak yang optimal terutama pada keluarga dengan lingkungan pengasuhan yang berkualitas rendah. Oleh sebab itu, perbaikan pada kualitas lingkungan pengasuhan dan kualitas pendidikan prasekolah diperlukan sebagai upaya dalam mengoptimalkan perkembangan kognitif anak pendidikan prasekolah

\section{DAFTAR PUSTAKA}

Aber, J. L., Bennet, N. G., Conley, D. C., \& Li, J. (1997). The effects of poverty on child health and development. Annual Reviews 
Inc, 18(4), 63-83. doi:10.1146/annurev. publhealth.18.1.463.

Anders, Y., Rossbach, H., Weinert, S., Ebert, S., Kuger, S., Lehrl, S., \& Maurice, J.V. (2012). Home and preschool learning environments and their relations to the development of early numeracy skills. Early Childhood Research Quarterly, 27(2), 231-244. doi:10.1016/j.ecresq. 2011.08.003.

Anderson, L. M., Shinn, C., Fullilove, M. T., Scrimshaw, S. C., Fielding, J. E., Normand, J., Carande-Kulis V. G., \& Task Force on Community Preventive Services. (2003). The effectiveness of early childhood development programs. Am J Prev Med, 24(3), 32-46. doi:10.1016/S0749-3797(02) 00655-4.

Andrade, S. A., Santos, D. N., Bastos, A. C., Pedromônico, M. R. M., Almeida-Filho, N., \& Barreto, M. L. (2005). Family environment and child's cognitive development: An epidemiological approach. Rev Saúrde Púpblica, 39(4), 1 6. doi:10.1590/S0034-891020050004 00014.

Barnett, W. S. (1995). Long-term effects of early childhood programs on cognitive and school outcomes. Winter, 5(3), 2550 .

Barnett, W. S., \& Ackerman, D. J. (2006). Costs, benefits, and long-term effects of early care and education programs: recommendations and cautions for community developers. Journal of the Community Development Society, 37(2), 86-100.

Burger, K. (2010). How does early childhood care and education affect cognitive development? an international review of the effects of early interventions for children from different social backgrounds. Early Childhood Research Quarterly, 25(2):140-165. doi:10.1016/ j.ecresq.2009.11.001.

Caldwell, B. M., \& Bradley, R. H. (2003). Home inventory administration manual. Arkansas, US: University of Arkansas.

Camargo-Fuguera. F., Barros, A. J. D., Santos, I. S., Matijasevich, A., \& Barros, F. C. (2014). Early life determinants of low IQ at age 6 in children from 2004 Pelotas Birth Cohort: a predictive approach. BMC Pediatrics, 14(308), 1-12. doi:10.1186/ s12887-014-0308-1.
Camilli, G., Vargas, S., Ryan, S., \& Barnett, W.S. (2010). Meta-analysis of the effects of early education interventions on cognitive and social development. Teachers College Record, 112(3), 579620.

Davis-Kean, P. E. (2005). The influence of parent education and family income on child achievement: The indirect role of parental expectations and the home environment. Journal of Family Psychology, 19(2), 294-304. doi:10.1037/ 0893-3200.19.2.294

Dearing, T., \& Taylor, B.A. (2007). Home improvement: within-family association between income and quality of children's home environment. Journal of Applied Developmental Psychology, 28(5-6), 427444. doi: 10.1016/j.appdev.2007.06.008.

[Depdiknas] Departemen Pendidikan Nasional. (2004). Instrumen perkembangan kognitif anak. Jakarta, ID: Depdiknas.

Eamon, M. K. (2001). The Effects of poverty on children's socioemotional development: An ecological systems analysis. Social Work, 46(3), 256-266. doi: 10.1093/sw/46.3.256.

Elmanora, Hastuti, D., \& Muflikhati, I. (2015). Kesejahteraan keluarga dan kualitas lingkungan pengasuhan pada anak usia prasekolah. Jurnal IImu Keluarga dan Konsumen, 8(2), 96-105. doi:10.24156/ jikk.2015.8.2.96.

Grantham-McGregor, S., Cheung, Y.B., Cueto, S., Glewwe, P., Richter, L., Strupp, B., \& The International Child Development Streering Group. (2007). Developmental potential in the first 5 years for children in developing countries. Lancet, 369(9555), 60-70. doi:10.1016/S0140-6736(07)600 32-4.

Harden, B. J., \& Whittaker, J. W. (2011). The early home environment and developmental outcomes for young children in the child welfare system. Children and Youth Services Review, 33(8), 1392-1403. doi:10.1016/j.child youth.2011.04.009

Hastuti, D., \& Alfiasari. (2008). Stimulasi psikososial dan pengaruhnya pada karakter anak yang bersekolah dan tidak bersekolah di Taman Bermain Semai Benih Bangsa, Kabupaten Aceh Utara, Provinsi NAD. Jurnal IImu Keluarga dan Konsumen, 1(2), 141-152. doi:10.24156/ jikk.2008.1.2.141. 
Hastuti, D. (2009). Stimulasi psikososial pada anak kelompok bermain dan pengaruhnya pada perkembangan motorik, kognitif, sosial emosi, dan moral/karakter anak. Jurnal IImu Keluarga dan Konsumen, 2(1):41-56. doi:10.24156/jikk.2009.2.1.41.

Hastuti, D., Alfiasari, \& Chandriyani. (2010). Nilai anak, stimulasi psikososial, dan perkembangan kognitif anak usia 2-5 tahun pada keluarga rawan pangan di Kabupaten Banjarnegara, Jawa Tengah. Jurnal IImu Keluarga dan Konsumen, $3(1)$,

27-34. doi:10.24156/jikk.2010.3.1.27.

Hastuti, D., Fiernanti, D. Y. I., \& Guhardja, S. (2011). Kualitas lingkungan pengasuhan dan perkembangan sosial emosi anak usia balita di daerah rawan pangan. Jurnal IImu Keluarga dan Konsumen, $4(1)$, 57-65. doi:10.24156/jikk.2011.4.1.57.

Heckman, J. J. (2008). Schools, skills, and synapses. Economic Inquiry, 46(3), 289324. doi:10.1111/j.1465-7295.2008.001 63.x.

Hoghughi, M. (2004). Parenting. Hoghughi, M., \& Long, N, editor. Handbook of parenting. London, UK: Sage Publications, Inc.

Holden, G. W. (2010). Parenting: a dynamic perspective. New York, US: Sage Publications, Inc.

Kiernan, K. E., \& Huerta, M. C. (2008). Economic deprivation, maternal depression, parenting and children's cognitive and emotional development in early childhood. The British Journal of Sociology, 59(4), 783-806. doi:10.1111/j.1468-4446.2008.00 219.x.

Klebanov, P. K., Brooks-Gunn, J., \& Duncan, G.J. (1994). Does neighborhood and family poverty affect mothers' parenting, mental health, and social support? Journal of Marriage and the Family, 56(2), 441-455. doi:10.2307/353111.

Latifah, M., Alfiasari, \& Hernawati, N. (2009). Kualitas tumbuh kembang, pengasuhan orang tua, dan faktor risiko komunitas pada anak usia prasekolah wilayah pedesaan di Bogor. Jurnal IImu Keluarga dan Konsumen, 2(2), 143-153. doi:10.24156/jikk.2009.2.2.143.

Latifah, E., Hastuti, D., \& Latifah, M. (2010). Pengaruh pemberian ASI dan stimulasi psikososial terhadap perkembangan sosial-emosi anak balita pada keluarga ibu bekerja dan tidak bekerja. Jurnal IImu Keluarga dan Konsumen, 3(1), 35-45. doi:10.24156/jikk.2010.3.1.35.

Lugo-Gil, J., \& Tamis-LeMonda, C.S. (2008). Family resources and parenting quality: links to children's cognitive development across the first 3 years. Child Development, 79(4), 1065-1085. doi: 10.1111/j.1467-8624.2008.01176.x.

[NAEYC] National Association for the Education of Young Children. (2013). NAEYC early childhood program standards and accreditation criteria and guidance for assessment. Diunduh dari: www. naeyc.org/files/academy/file/AllCriteriaDo cument.pdf.

Olaleye, O., Florence, O., \& Omotayo, K.A. (2009). Assessment of quality in early childhood education in Ekiti-State Nigeria. World Applied Sciences Journal, 7(5), 683-688.

Pachter, L. M., Auinger, P., Palmer, R., \& Weitzman, M. (2006). Do parenting and the home environment, maternal neighborhood, and chronic poverty affect child behavioral problems differentially in different racial-ethnic groups?. Pediatrics. 117(4), 1329-1338. doi:10.1542/peds.20 05-1784.

Papalia, D. E., Old, S. W., \& Feldman, R. D. (2008). Human development. Ed ke-9. New York, US: McGraw-Hill.

Rahmaulina, N. D., \& Hastuti, D. (2008). Hubungan pengetahuan ibu tentang gizi dan tumbuh kembang anak serta stimulasi psikososial dengan perkembangan kognitif anak usia 2-5 tahun. Jurnal IImu Keluarga dan Konsumen, 1(2), 171-181. doi:10.24156/ jikk.2008.1.2.166.

Ramey, C. T., Campbell, F. A., Burchinal, M., Skinner, M. L., Gardner, D. M., \& Ramey, S. L. (2000). Persistent effects of early childhood education on high-risk children and their mothers. Applied Developmental Science, 4(1), 2-14. doi: 10.1207/S1532480XADS0401_1.

Rao, N. (2010). Quality matters: observations from early childhood programs in low resource environment in Asia. World Conference on Early Childhood Care and Education: Building the wealth of Nations. Moscow, 27-29 September 2010.

Santrock, J. W. (2009). Child development. twelfth edition. New York, US: McGrawHill. 
Tucker-Drob, E. M., \& Harden, K. P. (2011). Early childhood cognitive development and parental cognitive stimulation: evidence for reciprocal geneenvironment transactions. Developmental Science, 15(2), 250-259. doi:10.1111/ j.1467-7687. 2011.01121.x

Welsch, D. M., \& Zimmer, D. M. (2010). The effect of health and poverty on early childhood cognitive development. Atlantic Economic Journal, 38(1), 37-49. doi:10.1007/s11293-009-9198-2.

Zevalkink, J., Riksen-Walraven, J. M., \& Bradley, R. H. (2008). The quality of children's home environment and attachment security in Indonesia. The Journal of Genetic Psychology, 169(1), 72-91. doi:10.3200/GNTP.169.1.72-91. 